\title{
A Systematic Review of Urban Sustainability Assessment Literature
}

\author{
Matthew Cohen \\ Department of Earth and Environmental Sciences, Furman University, Greenville, SC 29613, USA; \\ Matthew.Cohen@Furman.edu; Tel.: +1-864-294-2505
}

Received: 11 October 2017; Accepted: 3 November 2017; Published: 8 November 2017

\begin{abstract}
As the world rapidly urbanizes, there is much focus on achieving sustainability outcomes within cities. Accomplishing this goal requires not only envisioning sustainable cities and implementing strategies, but it also demands assessing progress towards sustainable urban development. Despite a growing literature on sustainability assessment, there is room to further understand the application of sustainability assessment in urban contexts. This paper presents a systematic review of urban sustainability assessment literature to (1) identify the most common methods used for urban sustainability assessment, (2) identify the most common framings for urban sustainability assessment, and (3) identify the most common categories for organizing indicators that measure urban sustainability. This research finds that urban sustainability assessment in general lacks a unifying framing and that it could be better aligned with common sustainability principles. The paper provides recommendations for future urban sustainability assessment research, including the employment of mixed-methods research among other strategies. In closing, this research offers a generic framework around which to structure urban sustainability assessment and within which to assign indicators for measuring progress towards sustainable urban development.
\end{abstract}

Keywords: sustainability assessment; sustainable cities; urban sustainability assessment; sustainable urban development

\section{Introduction}

As the world rapidly urbanizes, achieving sustainability in cities is quickly becoming a global concern [1,2]. Indeed, $54 \%$ of the world population was urban in 2014 , and the global urban population is projected to reach $66 \%$ by 2050 [3]. While cities can be centers of innovation and cross-cultural collaboration, the ecological footprint of the world's cities extends far beyond these urban centers' physical boundaries, and glaring socio-economic disparities exist within and between cities [4]. As such, scholars and practitioners are seeking and implementing strategies to shrink cities' impacts on the planet while improving quality of life for all peoples, both today and in the future.

Given the concerted efforts to achieve urban sustainability, there is also a need to set goals and targets and track progress towards urban sustainability outcomes. In this light, sustainability assessment provides a framing for better defining and understanding the sustainability enterprise for multiple domains, including urban development [5-8].

Urban sustainability is one topic area to which sustainability assessment is being applied, and urban sustainability assessment is a quickly growing subfield of sustainability assessment (see $[9,10])$; however, the literature is more developed for sustainability assessment in generic terms (see $[5,6])$ as well as in application to other areas of focus. This paper seeks to better understand how one might operationalize urban sustainability assessment to guide sustainable urban development. This research does so through a systematic review of urban sustainability assessment literature to meet the following objectives: (1) identify the most common methods used for urban sustainability 
assessment, (2) identify the most common framings for urban sustainability assessment, and (3) identify the most common categories for organizing indicators that measure urban sustainability. By reviewing the literature guided by these objectives, this paper reports on general themes and trends in urban sustainability assessment literature.

This paper understands sustainability as an endeavor to bring society within the Earth's planetary boundaries while lifting the global population above a basic standard of living [11-14]. Given this framing, sustainable cities would be urban areas whose surroundings are planned and managed to not drive environmental pressures beyond key thresholds while providing for livelihood and equity concerns of all inhabitants. To measure and assess progress towards this undertaking, there are multiple ways to frame indicators for understanding urban sustainability. In one example of framing, Forman and $\mathrm{Wu}$ [15] identify seven key areas of impact from urban expansion: natural vegetation, agricultural land, clean water, jobs, housing, transport, and communities. Here, there is a balanced perspective on urban development's impact on natural resources, natural services, basic human needs, and livelihoods.

Sustainability assessment is one tool that can be employed for better conceptualizing and defining urban sustainability. There exist countless resources on sustainability assessment across sectors and scales, as well as a growing body of research on sustainability assessment for the urban context. At the urban scale, sustainability assessment typically revolves around identifying and measuring indicators, and there are papers published that provide indicator sets numbering in the hundreds (see [16-19]).

Although there is an array of types of potential sustainability assessment frameworks [20], and identifying and measuring indicators is often at the heart of sustainability assessment, indicator selection for urban sustainability assessment is not often guided by a theoretical framework because literature framing sustainability assessment has often targeted national and global scales instead [9,21-23]. This may be problematic, as key principles of sustainable development should be followed when selecting sustainability indicators [24].

As a result, urban sustainability assessment often follows a three-silo approach, selecting and organizing indicators by economic, social, and environmental concerns, which impairs ones' ability to understand the interdependence of these three domains [9,10,22]. Davidson et al. [9] argue that this triple bottom line approach to sustainability assessment is an oversimplification of a complex problem and that the approach also fails to award equal or appropriate weight to each of the three pillars. Ding et al. [10] expand on this argument and claim that urban sustainability assessment must look beyond the three pillars and consider also "spatial, chronological and logical (64)" dimensions as well. Gibson [6], writing on sustainability assessment in general terms, asserts that sustainability assessment needs to be designed in an integrative approach that can match the integrative nature of the science.

Following these critiques, the inability for sustainability assessment to cross pillars is reductionist in nature [25], and a siloed approach carries limitations. For instance, weak theoretical framing allows for the possibility for indicators to be selected based on data availability, leading to cherry picking of available indicators without thinking through integration [26]. Furthermore, simply grouping indicators by pillar can be both ineffective and inefficient: a proliferation of indicator sets creates a challenge for comparing assessments across diverse cities, complicating the interpretation of results for both researchers and policy makers.

As cities are complex systems nested within and interconnected with unique ecological systems, with each city defined by its own cultural and historical context, it is quite challenging to adequately select from the hundreds_-or possibly thousands—of indicators to apply a uniform assessment to all urban areas around the world [27]. Therefore, it may prove more beneficial-and possible to instead align a generic urban sustainability assessment around a common set of guiding principles that frame criteria and indicators unique to each individual city. There are a number of theoretical frameworks developed for un-contextualized, or generic, sustainability assessment (see [6] for one example). In these cases, sustainability assessment is framed around guiding principles, for which scholars and practitioners can set goals and objectives as well as tangible indicators to measure progress. 


\section{Materials and Methods}

This study presents a systematic literature review [28-30] of the literature on urban sustainability assessment, following Preferred Reporting Items for Systematic Reviews and Meta-Analyses (PRISMA) guidelines [31]. The specific methods for this study, following the cited protocol, are presented in Section 2.1. After a search for literature, the research employed a content analysis to identify themes and organize qualitative data from the literature to better understand how sustainability assessment is applied in urban contexts.

\subsection{Systematic Literature Review}

The search term

“(sustain* (assessment OR appraisal) AND (principle* or goal* or objective* or indicator*) AND (urban OR public OR community))"

was used in Web of Science, Academic Search Premier, and GreenFILE. Web of Science was used because it is a large search system that employs multiple databases. While Web of Science results can be limited by citation distributions, it reliably searches across publishers and does not bias towards journals published by any one company. While Web of Science may apply too much rigor in its searches, it was chosen over Google Scholar, which does not apply enough rigor in vetting included resources. To address the limitations of Web of Science, Academic Search Premier was selected to capture additional sources. GreenFILE was used for its ability to return resources from scholarly as well as governmental and general-interest sources to ensure a diversity of included resources. The date parameters 2001-2017 were used, which the databases cover. The date range was used to narrow results to those published during the period after sustainability science was identified as a unique discipline [32], and the search inspected all records published until April 2017. Only peer-reviewed journal articles published in English were considered. A grey literature search was performed with the exact same search terms using Google's general search engine. Also, leading practitioner-based assessment protocols that were identified in the included articles were also used for the study. These protocols include LEED-ND, BREEAM Communities, DGNB, CASBEE-UD, UN Shanghai Manual, and Abu Dhabi's Pearl Rating System. The review was restricted to articles regarding sustainability assessment in urban contexts, but articles generated by the search terms focusing on generic sustainability assessment (for instance [6]) were included as well. Though such studies do not address urban assessment specifically, they are often cited as grounding for a wide range of sustainability assessment methods and have been cited in urban sustainability assessment literature [33,34]. In total, these search methods identified 3163 records.

The review includes studies from urban development to regional scales as well as cases from around the world. Diverse scales were used based on the need to situate a city within a multi-scale context [35] and design sustainability interventions that integrate across spatial scales [36]. Including cases from diverse contexts around the world can create confusion for analysis, but ultimately excluding cases based on location would also lose valuable lessons and insights. For instance, while cities around the world may face different realities particular to their individual contexts, there is value in reading broadly across all available cases. While a study of urban sustainability in Manila, Philippines may identify eradication of HIV / AIDS and malaria as urban development goals [37], case studies from the Global North may not identify these illnesses as relevant concerns, but many do articulate public health as important $[38,39]$. Furthermore, megacities in the Global South face much different realities than cities between 500,000 and one million residents in the United States. While realities of slum settlements and public housing may be different, in both cases, access to good, safe, affordable housing is a clear need. As such, despite stark contrasts in urban realities, thematic coding of the research on urban sustainability assessment can yield overarching elements that might be relevant to diverse contexts. In this vein, this research draws on lessons from the wide array of urban areas around the world. 
The review excluded redundant studies. For instance, Mori and Yamashita [40] provide a methodological framework for developing a city sustainability index. Mori et al. [41] then apply that same framework in an empirical study. Although the studies are different, they apply the same framework by the same author, and thus Mori et al. [41] was excluded to avoid double counting the indicator categories. Countering this exclusion criterion, some studies cited the same frameworks, for instance multiple authors employed the frameworks established by the most ubiquitously used rating systems (i.e., LEED-ND, BREEAM Communities, etc.). Each of these studies were included in order for the analysis to count how many unique authors used this framing, whereas the example at the beginning of this paragraph demonstrates a scholar continuing to use their own framework. Figure 1 presents a PRISMA flow diagram of the literature search and review.

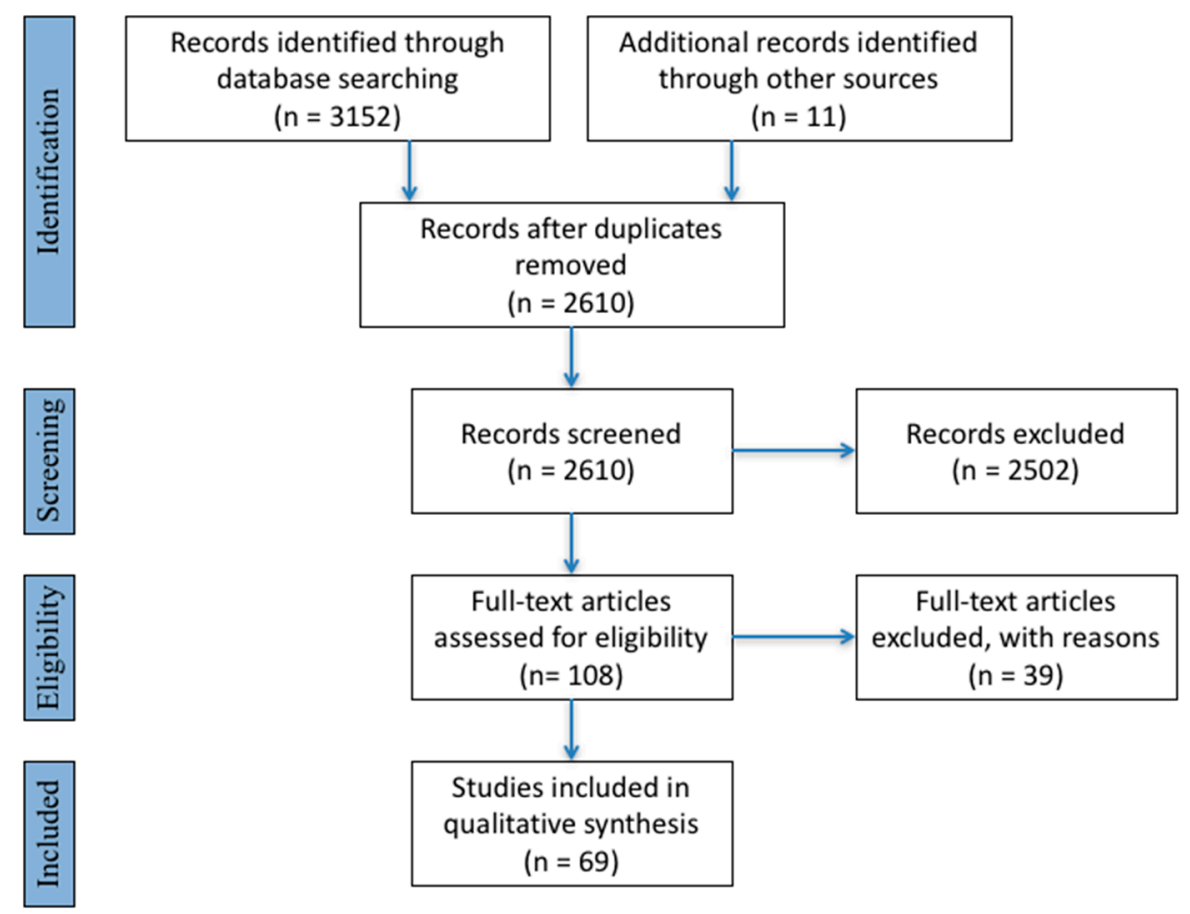

Figure 1. PRISMA Flow diagram of literature search and review.

\subsection{Content Analysis}

Once the 69 sources were selected for inclusion in the study, each source was read in full for a qualitative content analysis. Information regarding sustainability assessment applied either in urban contexts or generically was recorded in a spreadsheet. The spreadsheet was organized by columns for categories that were established a priori: principles, goals, objectives, and indicators. As the literature was reviewed, additional categories were added: themes, criteria, and sub-indicators. Data from the literature was added to corresponding cells under the categories as they were identified by the author.

Across the literature, there exist significant inconsistencies in how terms are defined. For instance, what one author considers a criterion, another might treat as an indicator. Likewise, there is much conflation between goals and objectives. As such, for the analysis, the data was coded in MaxQDA under more general terms, including "principles", "dimensions", and "categories". These designations are further explained with the research results.

Despite the efforts to systematically assemble a sound set of studies, there are of course limitations to this research. First, the study is limited to journal articles found by the selected databases. Second, the content analysis is based on the results reported by other authors, and there is little space to control for quality and completeness of others' results as well as the selective biases of the authors. Still, this research presents a broad reading of the literature and finds trends consistently reported by others. 


\section{Results}

Table 1 presents the articles included in the analysis. For each article, the table lists a citation, the general topic of the article, the spatial scale analyzed, and the location of study. Some of the sources were theoretical in nature, or did not include empirical research tied to a specific geography. These particular sources are noted as "Not scale or sector specific" (column: "Spatial Scale") and "Not spatially explicit" (column: "Locations").

Table 1. Included literature for the systematic review $(n=69)$.

\begin{tabular}{|c|c|c|c|c|}
\hline & Source & Topic & Spatial Scale & Locations \\
\hline 01 & Abdullahi et al. [42] & Compact urban form & Urban zones to city & Kajang, Malaysia \\
\hline 02 & $\begin{array}{l}\text { Abu Dhabi Urban } \\
\text { Planning Council [43] }\end{array}$ & Pearl Rating System for Estidama & Neighborhood & Abu Dhabi, UAE \\
\hline 03 & Al Waer and Kirk [44] & $\begin{array}{l}\text { Community } \\
\text { sustainability assessment }\end{array}$ & Neighborhood & United Kingdom \\
\hline 04 & Ameen et al. [19] & $\begin{array}{l}\text { Urban design and } \\
\text { urban development }\end{array}$ & Development project to city & Not spatially explicit \\
\hline 05 & Atkisson and Hatcher [38] & Sustainability indicators index & City to county & Orlando, United States \\
\hline 06 & Berardi [45] & $\begin{array}{l}\text { Multi-criteria rating systems for } \\
\text { urban communities }\end{array}$ & Neighborhood & Not spatially explicit \\
\hline 07 & Blackwood et al. [39] & $\begin{array}{l}\text { Urban sustainability assessment; } \\
\text { SAVE framework }\end{array}$ & Development project & Dundee, Scotland \\
\hline 08 & Bourdic et al. [46] & Urban form & Multiple urban scales & Not spatially explicit \\
\hline 09 & Boyko et al. [17] & $\begin{array}{l}\text { Urban regeneration and } \\
\text { future scenarios }\end{array}$ & Multiple urban scales & United Kingdom \\
\hline 10 & Braulio-Gonzalo et al. [47] & $\begin{array}{l}\text { Urban sustainability } \\
\text { assessment tools }\end{array}$ & Neighborhood and city & A Mediterranean city, Spain \\
\hline 11 & BREEAM [48] & BREEAM Communities & $\begin{array}{l}\text { Moderate and large } \\
\text { development projects }\end{array}$ & United Kingdom \\
\hline 12 & Browne et al. [49] & Sustainability metric tools & Town & Tipperary Town, Ireland \\
\hline 13 & Cappuyns [50] & $\begin{array}{l}\text { Social indicators for decision } \\
\text { support tools }\end{array}$ & Site & United Kingdom \\
\hline 14 & Murakami et al. [51] & CASBEE & City & Japan \\
\hline 15 & Cavalcanti et al. [52] & Urban mobility projects & Metropolitan region & Curitiba, Brazil \\
\hline 16 & Chesson [23] & $\begin{array}{l}\text { Asset-based framework for } \\
\text { sustainability assessment }\end{array}$ & Not scale or sector specific & Not spatially explicit \\
\hline 17 & Ciegis [24] & $\begin{array}{l}\text { Generic sustainability indicators } \\
\text { and principles }\end{array}$ & Not scale or sector specific & Not spatially explicit \\
\hline 18 & Cruz and Marques [53] & Municipal scorecard & City & Lisbon, Portugal \\
\hline 19 & Davidson et al. [9] & Social democratic approach & Multiple urban scales & Australia \\
\hline 20 & Dezelan et al. [54] & $\begin{array}{l}\text { Assessment of local strategic } \\
\text { planning mechanisms }\end{array}$ & Small municipality to city & 4 municipalities in Slovenia \\
\hline 21 & Ding et al. [10] & $\begin{array}{l}\text { Multi-dimensional framework for } \\
\text { sustainability assessment }\end{array}$ & City & Xi'an, China \\
\hline 22 & Egilmez et al. [55] & $\begin{array}{l}\text { Fuzzy Multi Criteria } \\
\text { Decision Making }\end{array}$ & Metropolitan region & $\begin{array}{l}27 \text { metropoles in US } \\
\text { and Canada }\end{array}$ \\
\hline 23 & Elgert [56] & STAR Communities & City & North America \\
\hline 24 & Estoque and Murayama [57] & Urban sustainability assessment & Town to city & Baguio City, the Philippines \\
\hline 25 & Fitzgerald et al. [58] & $\begin{array}{l}\text { Sustainability Evaluation Metric } \\
\text { for Policy Recommendations } \\
\text { (SEMPRe) }\end{array}$ & $\begin{array}{l}\text { Small to medium urban } \\
\text { settlement }\end{array}$ & 79 urban settlements, Ireland \\
\hline 26 & Gibson [6] & $\begin{array}{l}\text { Generic criteria for } \\
\text { sustainability assessments }\end{array}$ & Not scale or sector specific & Not spatially explicit \\
\hline 27 & Gonzalez et al. [27] & $\begin{array}{l}\text { Urban metabolism and decision } \\
\text { support systems }\end{array}$ & City & 5 cities across Europe \\
\hline 28 & Gutowska et al. [59] & $\begin{array}{l}\text { Sustainability indicator selection } \\
\text { at the local level }\end{array}$ & Community & Milanowek, Poland \\
\hline 29 & He et al. [60] & SEA and urban planning & Urban district & Changzhou City, China \\
\hline 30 & Huang et al. [61] & Sustainability indicators & City to urban region & Urban Taiwan \\
\hline
\end{tabular}


Table 1. Cont.

\begin{tabular}{|c|c|c|c|c|}
\hline & Source & Topic & Spatial Scale & Locations \\
\hline 31 & Huang et al. [62] & $\begin{array}{l}\text { Material/substance flow analysis } \\
\text { as SD assessment }\end{array}$ & Not scale or sector specific & Not spatially explicit \\
\hline 32 & Huang et al. [63] & Urban metabolism & City & Beijing, China \\
\hline 33 & Huang et al. [64] & $\begin{array}{l}\text { Sustainability indicators and } \\
\text { indices }\end{array}$ & City to landscape & Not spatially explicit \\
\hline 34 & Komeily and Srinivasan [65] & $\begin{array}{l}\text { Neighborhood sustainability } \\
\text { assessment tools }\end{array}$ & Development project to city & Not spatially explicit \\
\hline 35 & Kropp and Lein [66] & Multicriteria decision analysis & City & Worcester, MA, USA \\
\hline 36 & $\begin{array}{l}\text { Lamorgese and } \\
\text { Geneletti [33] }\end{array}$ & SEA & City & 15 cities in Italy \\
\hline 37 & Lavalle et al. [67] & Urban land use change & Megacity & $\begin{array}{l}5 \text { Central and Eastern } \\
\text { European cities; } \\
7 \text { non-European megacities }\end{array}$ \\
\hline 38 & Lin et al. [68] & $\begin{array}{l}\text { Urban eco-efficiency; } \\
\text { environmental footprint }\end{array}$ & City & Xiamen, China \\
\hline 39 & Masnavi [69] & Sustainability indicators & City & Not spatially explicit \\
\hline 40 & $\begin{array}{l}\text { McGranahan and } \\
\text { Satterthwaite [70] }\end{array}$ & Sustainable development in cities & City to region & Not spatially explicit \\
\hline 41 & Michael et al. [71] & Urban sustainability indicators & City & $\begin{array}{l}\text { Cities in Malaysia, China, } \\
\text { and Taiwan }\end{array}$ \\
\hline 42 & $\begin{array}{l}\text { Mitropoulos and } \\
\text { Prevedouros [72] }\end{array}$ & $\begin{array}{l}\text { Sustainability assessment of } \\
\text { urban transportation }\end{array}$ & Urban corridor & Honolulu, United States \\
\hline 43 & Mörtberg et al. [73] & $\begin{array}{l}\text { LEAM (Landuse Evoluation and } \\
\text { impact Assessment Model) }\end{array}$ & Metropolitan region & Stockholm, Sweden \\
\hline 44 & Mori and Christodoulou [74] & City sustainability index & City & Not spatially explicit \\
\hline 45 & Mori and Yamashita [40] & City sustainability index & City & Not spatially explicit \\
\hline 46 & Munier [75] & $\begin{array}{l}\text { Linear programming for } \\
\text { selecting indicators }\end{array}$ & City & North American city \\
\hline 47 & Olalla-Tarraga [20] & $\begin{array}{l}\text { Combination frameworks for SA } \\
\text { of urban ecological systems }\end{array}$ & City & Not spatially explicit \\
\hline 48 & Porio [37] & Quality of life frameworks & Metropolitan region & Manila, Philippines \\
\hline 49 & Reith and Orova [76] & Green neighborhood ratings & Neighborhood & Not spatially explicit \\
\hline 50 & Ries et al. [77] & Water utility assessment & City water utility & $\begin{array}{l}\text { United States urban } \\
\text { water utilities }\end{array}$ \\
\hline 51 & Schetke et al. [78] & $\begin{array}{l}\text { MCA and decision support } \\
\text { system for infill and greenfield } \\
\text { development }\end{array}$ & Development sites & Essen, Germany \\
\hline 52 & Sciopini et al. [79] & ISO 14031 standard & City & Padua, Italy \\
\hline 53 & Sharifi and Murayama [80] & $\begin{array}{l}\text { Neighborhood Sustainability } \\
\text { Assessment Tools }\end{array}$ & Neighborhood & Not spatially explicit \\
\hline 54 & Sharifi and Murayama [81] & $\begin{array}{l}\text { Neighborhood Sustainability } \\
\text { Assessment Tools }\end{array}$ & Neighborhood & $\begin{array}{l}\text { Portland, United States; } \\
\text { Salford, England; } \\
\text { Koshigaya, Japan }\end{array}$ \\
\hline 55 & Shen et al. [82] & $\begin{array}{l}\text { International Urban Sustainability } \\
\text { Indicators List }\end{array}$ & City & $\begin{array}{l}9 \text { large cities around } \\
\text { the world }\end{array}$ \\
\hline 56 & $\begin{array}{l}\text { STAR Community } \\
\text { Rating System [83] }\end{array}$ & STAR Community Rating System & City & Not spatially explicit \\
\hline 57 & Stuart et al. [34] & Sustainability principles & City & $\begin{array}{l}4 \text { municipalities in } \\
\text { Ontario, Canada }\end{array}$ \\
\hline 58 & Sun et al. [84] & Sustainable development index & City to region & $\begin{array}{l}27 \text { provinces and } \\
4 \text { municipalities in China }\end{array}$ \\
\hline 59 & Tran [85] & $\begin{array}{l}\text { Sustainable urban development } \\
\text { indicators }\end{array}$ & City & $\begin{array}{l}\text { Durham, North Carolina, } \\
\text { United States }\end{array}$ \\
\hline 60 & USGBC [86] & LEED-ND v4 & Neighborhood & North America \\
\hline 61 & van Djik and Mingshun [87] & Sustainability indices & City & 4 medium cities in China \\
\hline 62 & Venkatesh et al. [88] & $\begin{array}{l}\text { Metabolism modelling for urban } \\
\text { water services }\end{array}$ & City water utility & Oslo, Norway \\
\hline 63 & Versovsek et al. [89] & Local spatial identities & Neighborhood & 6 neighborhoods, Slovenia \\
\hline 64 & Wangel et al. [90] & $\begin{array}{l}\text { Sustainable neighborhood } \\
\text { rating systems }\end{array}$ & Neighborhood & Not spatially explicit \\
\hline
\end{tabular}


Table 1. Cont.

\begin{tabular}{cllll}
\hline & \multicolumn{1}{c}{ Source } & \multicolumn{1}{c}{ Topic } & Spatial Scale & Locations \\
\hline 65 & Wei et al. [91] & Urban carrying capacity & City & Beijing, China \\
\hline 66 & Yigitcanlar et al. [35] & $\begin{array}{l}\text { Multi-scalar urban } \\
\text { sustainability assessment }\end{array}$ & Neighborhood to region & Gold Coast City, Australia \\
\hline 67 & Yin et al. [92] & Eco-efficiency & City & 30 provincial capitals, China \\
\hline 68 & Yoon and Park [93] & Sustainable material assessment & Neighborhood to city & $\begin{array}{l}\text { New York, London, } \\
\text { Seoul, Tokyo }\end{array}$ \\
\hline 69 & Zanella et al. [94] & City livability & City & 34 European cities \\
\hline
\end{tabular}

The first analysis looked to the assessment methods that are used across the literature. Sustainability assessment may be conducted by employing a variety of methods. Table 2 lists the research methods for organizing indicators used in the reviewed articles and shows the number of studies that applied each method.

Table 2. Urban sustainability assessment methods from the literature.

\begin{tabular}{cc}
\hline Method & Number of Instances in the Literature \\
\hline Indicator or index-oriented frameworks & 25 \\
Sustainability rating systems & 16 \\
Principle-based frameworks & 6 \\
Spatial analysis and urban form & 6 \\
Multi-criteria decision making & 5 \\
Urban metabolism & 5 \\
Eco-efficiency assessment & 2 \\
Impact assessment & 2 \\
Asset-based framework & 1 \\
Urban carrying capacity & 1 \\
\hline
\end{tabular}

A plurality of studies organized sustainability assessments around the selection and measuring of indicators. In most cases, indicators are here framed around traditional sustainability pillars or unclear framings. The next most common approach is to frame urban sustainability assessment around rating systems that group indicators under a series of criteria and tally points that a city or neighborhood earns for meeting certain criteria. Principle-based frameworks for urban sustainability assessment registered as a distant third, with six sources taking such an approach.

The next analysis of the literature's content sought to identify guiding principles for urban sustainability assessment. Admittedly, such a framing around guiding principles was not strong throughout the literature. Gibson [6] provided the clearest framing, and his generic criteria for sustainability assessment, though not explicitly written for the urban context, has been applied across multiple contexts and was used as an organizing theme for two other papers used in this study [33,34], and other authors articulated principles that if not precisely the same as Gibson's criteria, aligned with the intent. In these cases, such principles were coded by Gibson's terminology. Table 3 presents the principles and identifies the number of times each principle was found throughout the literature.

Table 3. Sustainability principles in the literature.

\begin{tabular}{cc}
\hline Principle & Number of Instances in the Literature \\
\hline Socio-ecological system integrity & 6 \\
Livelihood sufficiency and opportunity & 3 \\
Intragenerational equity & 5 \\
Intergenerational equity & 4 \\
Resource maintenance and efficiency & 5 \\
Precaution and adaptation & 3 \\
Immediate and long-term integration & 4 \\
Socio-ecological civility and democratic governance & 2 \\
\hline Adapted from: Gibson [6]
\end{tabular}


Rather than framing urban sustainability assessment around standard sustainability principles, a more common practice was to organize assessments under a pillars of sustainability approach. Here, the most conventional structure is to select and group indicators to measure the environmental, economic, and social performance of cities. Papers reviewed here also recommended additional pillars to augment the traditional three pillars perspective. Table 4 presents the pillars identified through the content analysis, here described as dimensions of sustainability, and reports the number of times each was used in the literature.

Table 4. Sustainability 'dimensions' identified in the literature.

\begin{tabular}{cc}
\hline Dimension & Number of Instances in the Literature \\
\hline Environmental & 26 \\
Social & 26 \\
Economic & 22 \\
Integrative & 17 \\
Institutional & 7 \\
Material & 3 \\
Urban form & 2 \\
Cultural & 1 \\
Energy & 1 \\
Technological & 1 \\
\hline
\end{tabular}

Twenty-six of the reviewed articles framed urban sustainability assessment through some combination of the traditional three pillars (environmental, economic, social). Of this total, one organized strictly around the three pillars, and 13 followed the three pillars but added an additional dimension, such as institutional to account for good governance arrangements. In addition, an integrative dimension appeared in some papers, allowing for tracking indicators at the interface of two pillars (i.e., socio-economic, social-environmental, environmental-economic).

Because there was not a consistent definition of terms across the literature, the data collected, whether it be framed as principles, pillars, dimensions, criteria, indicators, sub-indicators, etc., was ultimately catalogued and organized by category. Table 5 presents the categories for urban sustainability assessment that appeared across the literature. Here, the table lists the categories themselves, and it also states how many times an element related to each category appeared in the literature. For this, the table shows total instances in the literature, but it also reports the number of unique instances a relevant element appeared for each category. For example, assessment elements related to land use appeared 84 times and were used by 36 of the reviewed resources. However, across these 84 instances, many were repetitive: land use was mentioned generically 15 times, green and open spaces were discussed on 12 occasions, and urban form was studied in nine cases.

Table 5. Urban sustainability categories in the literature.

\begin{tabular}{cccc}
\hline Category & $\begin{array}{c}\text { Total Number of } \\
\text { Instances in the } \\
\text { Literature }\end{array}$ & $\begin{array}{c}\text { Number of Unique } \\
\text { Elements in the } \\
\text { Literature }\end{array}$ & $\begin{array}{c}\text { Number of Sources } \\
\text { Referencing }\end{array}$ \\
\hline Air Quality & 19 & 2 & 16 \\
Arts, Culture and Recreation & 40 & 15 & 22 \\
Buildings & 49 & 19 & 18 \\
Built Environment & 30 & 9 & 17 \\
Climate Change & 18 & 3 & 14 \\
Community & 22 & 9 & 15 \\
Economy & 104 & 41 & 40 \\
Education & 16 & 6 & 12 \\
Energy & 45 & 12 & 33 \\
Equity & 73 & 28 & 30 \\
Food Systems & 14 & 8 & 11 \\
Governance & 124 & 5 & 34 \\
Growth and development & 8 & 9 & 8 \\
Housing & 29 & 11 & 20 \\
Infrastructure & 29 & 13 & 36 \\
Land Use & 84 & &
\end{tabular}


Table 5. Cont.

\begin{tabular}{cccc}
\hline Category & $\begin{array}{c}\text { Total Number of } \\
\text { Instances in the } \\
\text { Literature }\end{array}$ & $\begin{array}{c}\text { Number of Unique } \\
\text { Elements in the } \\
\text { Literature }\end{array}$ & $\begin{array}{c}\text { Number of Sources } \\
\text { Referencing }\end{array}$ \\
\hline Management & 16 & 7 & 10 \\
Manufacturing & 6 & 4 & 6 \\
Material Use & 33 & 15 & 22 \\
Mobility and transportation & 76 & 19 & 32 \\
Natural Environment & 99 & 29 & 49 \\
Natural Resources & 41 & 18 & 27 \\
Pollution & 15 & 4 & 10 \\
Public Health & 32 & 14 & 16 \\
Quality of Life & 23 & 9 & 20 \\
Safety & 42 & 12 & 13 \\
Technology & 15 & 4 & 23 \\
Waste & 32 & 12 & 29 \\
Water & 64 & & 19 \\
\hline
\end{tabular}

\section{Discussion}

\subsection{Urban Sustainability Assessment Methods in the Literature}

As noted in the Results (Table 2), a plurality of studies employed indicator- or index-oriented frameworks (25 studies) and rating system frameworks (16 studies), which are similar in nature. This was not a surprising finding, as the general literature on urban sustainability assessment acknowledges that this is the most typical approach [9,21-23]. Although the indicator-based framework is the most common analytical tool, one should not necessarily blindly apply such an assessment protocol for future studies, as there are concerns in the literature that this approach is too often not grounded in clear sustainability principles and that indicators for urban sustainability assessment should be selected and organized through a more integrative perspective $[6,10,24]$. The following Sections 4.2 and 4.3 expand on this concern.

\subsection{Sustainability Principles in the Literature}

With calls in the literature to guide sustainability assessment with clear, integrative sustainability principles, it is necessary to ask how many of the included studies applied such a framing (Table 3). In fact, grounding urban sustainability assessment in foundational principles of sustainability science was not a common practice at all. Gibson [6] provided the clearest framing, and his generic criteria for sustainability assessment were applied by two other studies [33,34]. Based on the studies reviewed here, there is not a consensus for principle-based urban sustainability assessment frameworks, which creates an important research gap for future studies in this field.

\subsection{Sustainability Dimensions in the Literature}

The literature points out that sustainability dimensions (i.e., three pillars plus additionally proposed dimensions) present a common framing for sustainability indicator selection $[9,10,22]$. Table 4 supports this claim, showing that 22 studies applied a three pillars framework and 26 organized around environmental and social sustainability. This finding raises two concerns. First, other scholars have already questioned if a three pillars model is not an overly simple, reductionist approach to understanding complex problems that can lead to cherry-picking only convenient data $[9,25,26]$. Second, if a bulk of studies (perhaps unsophisticatedly) argue that sustainability is the intersection of environmental, social, and economic dimensions, then the set of studies that do not evenly apply all three dimensions might not be considering a full conceptualization of sustainability as it is conventionally conceived. These concerns align with the calls for more integrative and principles-based assessment frameworks. 


\subsection{Urban Sustainability Categories in the Literature}

The results in Table 5 are not surprising, as the categories represented in the literature are common issues in urban planning and development. The research question for future studies is how these categories can be operationalized as goals that strive towards pursuing guiding principles [95]. Then, indicators can be assigned to measuring the identified goals. Under such an arrangement, urban sustainability assessment would then become goal-oriented. [5,54,56,59]. Identifying actionable goals and objectives for each category and then organizing them around a framework of integrative principles might also allow for scholars and practitioners to better articulate, track progress towards, and assess the alignment between areas such as land use, transportation, and housing. In this case, such a framing would identify these categories (and their underlying goals and objectives) as critical to achieving resource efficiency, integrity of our social-ecological systems, and social equity outcomes.

\subsection{Recommendations}

Based on the literature, I offer here recommendations for future urban sustainability assessment research:

Standardize terms and concepts across urban sustainability assessment studies: The discussion in Sections 4.1-4.4 demonstrates that there is no clear organizational structure for urban sustainability assessment across the literature. The literature provided an array of methods and frameworks, as well as a myriad of organizational headers, with the most common being principles, categories, goals, objectives, practices, themes, criteria, indicators, and sub-indicators. Furthermore, across the reviewed papers, there was not necessarily common agreement as to what might constitute a category, a theme, or an indicator. What might be a criterion to one author might be presented as an indicator by another. Some studies framed assessments through a hierarchy of goals/objectives/indicators (for instance [56,71]), while others organized around categories/themes (for instance [35,37]). Likewise, some studies organized around guiding principles (for instance [33,34]), while others organized around the three pillars (for instance $[59,75]$ ). It is perfectly acceptable for disparate scholars to develop and apply unique frameworks, but it becomes challenging to draw conclusions across studies when the terminology they use is inconsistent with each other's. Therefore, it is critical for future studies to explore a common lexicon for the field.

Ground urban sustainability assessment in core sustainability principles: While scholars may design their own research framings, there is a clear need to further explore the efficacy of a principle-based assessment framework. The most prevalent organizing structure found in the literature is to base assessment around the three pillars, or in many cases the three pillars plus additional dimensions (Table 4). While this is the most common approach, there is ample debate in the literature regarding if such a framing is sufficient ([9]; as noted in Sections 1 and 4.3). One compelling option is to organize assessment around sustainability values and principles [25]. Within urban sustainability assessment literature, this is an underrepresented approach and requires further research. For instance, Gibson's eight criteria were the most coherent set of principles identified in this literature review, but there are arguments in the literature that core value sets should be limited to no more than five values $[96,97]$. A concise and coherent set of principles would provide a more integrative approach to planning for and assessing urban sustainability, helping to avoid the pitfalls of oversimplification and reductionism $[9,25]$.

Frame urban sustainability assessment around implementable goals that lead towards guiding principles: Sustainability science is a solution-oriented discipline [98], and framing urban sustainability assessment around goals for pursuing sustainability principles creates opportunity to employ urban sustainability assessment not just as a tool for ex post facto research, but to also guide sustainability visions and strategies for sustainable urban development. Using goals and objectives that work towards guiding principles allows researchers and practitioners to then select indicators that track genuine progress towards sustainability outcomes. As there is no unifying organizational structure embraced by the literature, a goal-based framework [20,56,59] would orient the descriptive-analytical task of sustainability assessment around the creation of solutions to sustainability problems. As such, urban 
sustainability assessment can then be more of a driver of change than a summative assessment tool. In this vein, urban sustainability assessment can be used as a visioning tool [95] to identify aspirational goals and objectives while also being implemented as a post-facto assessment tool as well. This proposal is supported by Reed et al. [99], who propose that sustainability indicators should not just be applied as a measurement tool, but rather they can be utilized to identify problems, set goals, and establish management strategies as well. Indeed, an evaluation tool's utility may be maximized when it can be used as an input for planning interventions and setting sustainability visions [79]. While this paragraph identifies calls in the literature for such a framing, it is not presently the most common practice, and there is little agreement across the literature regarding what constitutes goals, objectives, and other organizing terms. Therefore, there is presently a gap in the literature where goal-oriented urban sustainability assessments can become more ubiquitous and standardized.

Draw from diverse methods to perform urban sustainability assessment: To facilitate a holistic interpretation of sustainability, it may be necessary to employ mixed methods. For instance, assessing ecosystem services of a neighborhood's green infrastructure may tell how a neighborhood performs in carbon storage, biodiversity protection, or stormwater management, but such a study would need to be paired with a material flow analysis to determine if the neighborhood's built environment is consuming too much raw material or generating too much waste and emissions. Furthermore, without a governance study of how a vision was created or policy was set, it is impossible to judge if the process was fair and just or if outcomes meet the needs and interests of marginalized populations. Therefore, one might need to use material flow analysis, ecosystem services assessment, economic modeling, and include social indicators to generate a robust assessment. Such a mixed-methods approach may create challenges for prioritizing tradeoffs (for instance, balancing resource conservation with the need to create more equitable access to potentially scarce resources). Again, this highlights the need for more integrative perspectives on sustainability, whereas assessments organized around the siloed three pillars may overlook these tensions.

\subsection{Limitations}

There are some limitations to this analysis. For instance, this paper strictly reports what was found in the literature using the defined search parameters and screening methods. Also, one must apply a filter when interpreting the literature. The category economy provides a clear example. Economic growth was an underlying goal for many papers that discussed urban economies (for instance [71,91]). There is much discussion in the literature questioning if economic growth is incongruous with sustainability $[100,101]$. Given this ongoing debate and the fact that our global economy is surpassing biophysical limits at the planetary scale [11,14], one must ask what role urban economic growth can and should play in sustainable urban development, and what implications this debate might have for principles such as sustainable livelihoods. Therefore, a more accurate determination of the sustainability of a city's economy may ask whether the city provides meaningful livelihood opportunities for all inhabitants while maintaining its natural resource base and not compromising the quality of its surrounding natural environment. Under this perspective, there is not a clear indicator, such as GDP, that would provide a simple, digestible picture; however, such an assessment of a locale's economy would be more authentic from a strong sustainability perspective. This point highlights the weaknesses of siloed assessments based around the three pillars model and promotes the interest in more integrative conceptualizations and assessments of sustainable urban development $[9,10,22]$.

\section{Conclusions}

This paper reviewed the literature on urban sustainability assessment to identify the most common methods, framings and categorical topics that have been used to-date. Through an analysis of the literature, this paper concludes that the most common methods and framings-organizing large indicator sets around the three pillars and other dimensions-may not be the best course for planning future urban sustainability assessments. Instead, a more integrative approach in which core 
sustainability principles guide a goal-based framework should be employed. There are examples of such studies in the literature, but the practice is not ubiquitous nor is it standardized at present.

This paper is limited by its reliance on other scholars self-reporting results in their own studies. Furthermore, there are language inconsistencies across the literature in terms of what scholars identify as principles, goals, objectives, themes, criteria, indicators, and such. Therefore, the analysis of the literature is based on this author's interpretation of what is at times unclear work of others.

Still, this paper points to new research that would benefit the field of urban sustainability assessment. Primarily, future research will need to establish guiding principles (limited to five), build goal-oriented assessment frameworks under these principles, and test the frameworks with empirical assessment studies. This should be pursued in parallel with the development of a common lexicon to unify urban sustainability assessment literature. To be sure, there are already principle-based and goal-oriented studies published, but until this approach to urban sustainability assessment becomes more wide-spread and standardized, an understanding and research gap in this area will persist.

Acknowledgments: Funding: This work was supported by the David E. Shi Center for Sustainability (Furman University) Faculty Research Fellowship.

Conflicts of Interest: The author declares no conflict of interest.

\section{References}

1. Newman, P.; Jennings, I. Cities as Sustainable Ecosystems; Island Press: Washington, DC, USA, 2008.

2. Wu, J. Urban sustainability: An inevitable goal of landscape research. Landsc. Ecol. 2014, 25, 1-4. [CrossRef]

3. United Nations, Department of Economic and Social Affairs, Population Division. World Urbanization Prospects: The 2014 Revision, Highlights; United Nations: New York, NY, USA, 2015.

4. Keivani, R. A review of the main challenges to urban sustainability. Int. J. Urban Sustain. Dev. 2010, 1, 5-16. [CrossRef]

5. Pope, J.; Annandale, D.; Morrison-Saunders, A. Conceptualising sustainability assessment. Environ. Impact Assess. Rev. 2004, 24, 595-616. [CrossRef]

6. Gibson, R.B. Beyond the pillars: Sustainability assessment as a framework for effective integration of social, economic and ecological considerations in significant decision-making. J. Environ. Assess. Policy Manag. 2006, 8, 259-280. [CrossRef]

7. Ness, B.; Urbel-Piirsalu, E.; Anderberg, S.; Olsson, L. Categorising tools for sustainability assessment. Ecol. Econ. 2007, 60, 498-508. [CrossRef]

8. Kumar, R.; Murty, H.R.; Gupta, S.K.; Dikshit, A.K. An overview of sustainability assessment methodologies. Ecol. Indic. 2012, 15, 281-299. [CrossRef]

9. Davidson, K.M.; Kellett, J.; Wilson, L.; Pullen, S. Assessing urban sustainability from a social democratic perspective: A thematic approach. Local Environ. 2012, 17, 57-73. [CrossRef]

10. Ding, X.; Zhong, W.; Shearmur, R.G.; Zhang, X.; Huisingh, D. An inclusive model for assessing the sustainability of cities in developing countries - trinity of cities' sustainability from spatial, logical and time dimensions (TCS-SLTD). J. Clean. Prod. 2015, 109, 62-75. [CrossRef]

11. Rockstrom, J.; Steffen, W.; Noone, K.; Persson, A.; Chapin, F.S., III; Lambin, E.F.; Lenton, T.M.; Scheffer, M.; Folke, C.; Schellnhuber, H.-J.; et al. A safe operating space for humanity. Nature 2009, 461, 472-475. [CrossRef] [PubMed]

12. Raworth, K. A Safe and Just Space for Humanity: Can We Live within the Doughnut? Oxfam GB: Oxford, UK, 2012; pp. 1-26.

13. Dearing, J.A.; Wang, R.; Zhang, K.; Dyke, J.G.; Haberl, H.; Hossain, M.S.; Langdon, P.G.; Lenton, T.M.; Raworth, K.; Brown, S.; et al. Safe and just operating spaces for regional social-ecological systems. Glob. Environ. Chang. 2014, 28, 227-238. [CrossRef]

14. Steffen, W.; Richardson, K.; Rockström, J.; Cornell, S.E.; Fetzer, I.; Bennett, E.M.; Biggs, R.; Carpenter, S.R.; Vries, W.D.; Wit, C.A.D.; et al. Planetary boundaries: Guiding human development on a changing planet. Science 2015, 347, 1259855. [CrossRef] [PubMed]

15. Forman, R.T.T.; Wu, J. Where to put the next billion people. Nature 2016, 537, 608-611. [CrossRef] [PubMed] 
16. Xing, Y.; Horner, R.M.W.; El-Haram, M.A.; Bebbington, J. A framework model for assessing sustainability impacts of urban development. Account. Forum 2009, 33, 209-224. [CrossRef]

17. Boyko, C.T.; Gaterell, M.R.; Barber, A.R.G.; Brown, J.; Bryson, J.R.; Butler, D.; Caputo, S.; Caserio, M.; Coles, R.; Cooper, R.; et al. Benchmarking sustainability in cities: The role of indicators and future scenarios. Glob. Environ. Chang. Part Hum. Policy Dimens. 2012, 22, 245-254. [CrossRef]

18. Zhou, N.; He, G.; Williams, C. China's Development of Low-Carbon Eco-Cities and Associated Indicators Systems; Ernest Orlanda Lawrence \& Berkeley National Laboratory: Berkeley, CA, USA, 2012.

19. Ameen, R.F.M.; Mourshed, M.; Li, H. A critical review of environmental assessment tools for sustainable urban design. Environ. Impact Assess. Rev. 2015, 55, 110-125. [CrossRef]

20. Olalla-Tarraga, M.A. A conceptual framework to assess sustainability in urban ecological systems. Int. J. Sustain. Dev. World Ecol. 2006, 13, 1-15. [CrossRef]

21. Sumner, A. Measuring sustainable development in the era of globalisation: Can it be done and what way ahead? World Rev. Sci. Technol. Sustain. Dev. 2004, 1, 116-127. [CrossRef]

22. Davidson, K.M. Reporting systems for sustainability: What are they measuring? Soc. Indic. Res. 2011, 100, 351-365. [CrossRef]

23. Chesson, J. Sustainable development: Connecting practice with theory. J. Environ. Policy Manag. 2013, 15, 1350002-1-1350002-27. [CrossRef]

24. Ciegis, R.; Ramanauskiene, J.; Startiene, G. Theoretical reasoning of the use of indicators and indices for sustainable development assessment. Inzinerine Ekon.-Eng. Econ. 2009, 3, 33-40.

25. Sala, S.; Ciuffo, B.; Nijkamp, P. A systematic framework for sustainability assessment. Ecol. Econ. 2015, 119, 314-325. [CrossRef]

26. Keirstead, J.; Leach, M. Bridging the gaps between theory and practice: A service niche approach to urban sustainability indicators. Sustain. Dev. 2008, 16, 329-340. [CrossRef]

27. Gonzalez, A.; Donnelly, A.; Jones, M. Community of practice approach to developing urban sustainability indicators. J. Environ. Assess. Policy Manag. 2011, 13, 591-617. [CrossRef]

28. Mulrow, C.D. The medical review article: State of the Science. Ann. Intern. Med. 1987, 106, $485-488$. [CrossRef] [PubMed]

29. Velten, S.; Leventon, J.; Jager, N.; Newig, J. What is sustainable agriculture? A systematic review. Sustainability 2015, 7, 7833-7865. [CrossRef]

30. Yang, S.; Song, Y.; Tong, S. Sustainable retailing in the fashion industry: A systematic literature review. Sustainability 2017, 9, 1266. [CrossRef]

31. Moher, D.; Liberati, A.; Tetzlaff, J.; Altman, D.G.; The PRISMA Group. Preferred reporting items for systematic reviews and meta-analyses: The PRISMA statement. PLoS Med. 2009, 6, 1-6. [CrossRef] [PubMed]

32. Kates, R.W.; Clark, W.C.; Corell, R.; Hall, M.J.; Jaeger, C.C.; Lowe, I.; McCarthy, J.J.; Schellnhuber, H.-J.; Bolin, B.; Dickson, N.M.; et al. Sustainability science. Science 2001, 292, 641-642. [CrossRef] [PubMed]

33. Lamorgese, L.; Geneletti, D. Sustainability principles in strategic environmental assessment: A framework for analysis and examples from Italian urban planning. Environ. Impact Assess. Rev. 2013, 42, 116-126. [CrossRef]

34. Stuart, J.; Collins, P.; Alger, M.; Whitelaw, G. Embracing sustainability: The incorporation of sustainability principles in municipal planning and policy in four mid-sized municipalities in Ontario, Canada. Local Environ. 2016, 21, 219-240. [CrossRef]

35. Yigitcanlar, T.; Dur, F.; Dizdaroglu, D. Towards prosperous sustainable cities: A multiscalar urban sustainability assessment approach. Habitat Int. 2015, 45, 36-46. [CrossRef]

36. Schensul, J.J. Community, culture and sustainability in multilevel dynamic systems intervention science. Am. J. Community Psychol. 2009, 43, 241-256. [CrossRef] [PubMed]

37. Porio, E. Sustainable development goals and quality of life targets: Insights from Metro Manila. Curr. Sociol. Monogr. 2015, 63, 244-260. [CrossRef]

38. Atkinson, A.; Hatcher, L. The compass index of sustainability: Prototype for a comprehensive sustainability information system. J. Environ. Assess. Policy Manag. 2001, 3, 509-532. [CrossRef]

39. Blackwood, D.J.; Gilmour, D.J.; Isaacs, J.P.; Kurka, T.; Falconer, R.E. Sustainable urban development in practice: The SAVE concept. Environ. Plan. B 2014, 41, 885-906. [CrossRef]

40. Mori, K.; Yamashita, T. Methodological framework of sustainability assessment in city sustainability index (CSI): A concept of constraint and maximisation indicators. Habitat Int. 2015, 45, 10-14. [CrossRef] 
41. Mori, K.; Fujii, T.; Yamashita, T.; Mimura, Y.; Uchiyama, Y.; Hayashi, K. Visualization of a City Sustainability Index (CSI): Towards transdisciplinary approaches involving multiple stakeholders. Sustainability 2015, 7, 12402-12424. [CrossRef]

42. Abdullahi, S.; Pradhan, B.; Jebur, M.N. GIS-based sustainable city compactness assessment using integration of MCDM, Bayes theorem and RADAR technology. Geocarto Int. 2015, 30, 365-387. [CrossRef]

43. The Pearl Rating System for Estidama Community Rating System; Abu Dhabi Urban Planning Council: Abu Dhabi, UAE, 2010.

44. Alwaer, H.; Kirk, R.D. Matching a community assessment tool to the requirements of practice. Proc. Inst. Civ. Eng. Urban Des. Plan. 2015, 169, 216-229. [CrossRef]

45. Berardi, U. Sustainability assessment of urban communities through rating systems. Environ. Dev. Sustain. 2013, 15, 1573-1591. [CrossRef]

46. Bourdic, L.; Salat, S.; Nowacki, C. Assessing cities: A new system of cross-scale spatial indicators. Build. Res. Inf. 2012, 40, 592-605. [CrossRef]

47. Braulio-Gonzalo, M.; Dolores Bovea, M.; Jose Rua, M. Sustainability on the urban scale: Proposal of a structure of indicators for the Spanish context. Environ. Impact Assess. Rev. 2015, 53, 16-30. [CrossRef]

48. BREEAM Communities. BREEAM Communities Technical Manual; BREEAM Communities: Watford, UK, 2012; pp. 1-8.

49. Browne, D.; O’Regan, B.; Moles, R. A comparative analysis of the application of sustainability metric tools using Tipperary Town, Ireland, as a case study. Manag. Environ. Qual. Int. J. 2005, 16, 37-54. [CrossRef]

50. Cappuyns, V. Inclusion of social indicators in decision support tools for the selection of sustainable site remediation options. J. Environ. Manag. 2016, 184, 1-12. [CrossRef] [PubMed]

51. Murakami, S.; Asami, M.Y.; Ikaga, T.; Ishida, H.; Inoue, K.; Iwamura, K. Environmental Performance Assessment Tool for Municipalities: Overview of CASBEE for Cities; Comprehensive Assessment System for Built Environment Efficiency: Tokyo, Japan, 2013; pp. 1-3.

52. De Oliveira Cavalcanti, C.; Limont, M.; Dziedzic, M.; Fernandes, V. Sustainability assessment methodology of urban mobility projects. Land Use Policy 2017, 60, 334-342. [CrossRef]

53. Da Cruz, N.F.; Marques, R.C. Scorecards for sustainable local governments. Cities 2014, 39, $165-170$. [CrossRef]

54. Dezelan, T.; Maksuti, A.; Ursic, M. Capacity of local development planning in Slovenia: Strengths and weaknesses of local sustainable development strategies. Lex Localis J. Local Self-Gov. 2014, 12, 547-573. [CrossRef]

55. Egilmez, G.; Gumus, S.; Kucukvar, M. Environmental sustainability benchmarking of the U.S. and Canada metropoles: An expert judgment-based multi-criteria decision making approach. Cities 2015, 42, 31-41. [CrossRef]

56. Elgert, L. The double edge of cutting edge: Explaining adoption and nonadoption of the STAR rating system and insights for sustainability indicators. Ecol. Indic. 2016, 67, 556-564. [CrossRef]

57. Estoque, R.C.; Murayama, Y. Measuring sustainability based upon various perspectives: A case study of a hill station in Southeast Asia. AMBIO 2014, 43, 943-956. [CrossRef] [PubMed]

58. Fitzgerald, B.G.; O'Doherty, T.; Moles, R.; O'Regan, B. A quantitative method for the evaluation of policies to enhance urban sustainability. Ecol. Indic. 2012, 18, 371-378. [CrossRef]

59. Gutowska, J.; Sleszynski, J.; Grodzinska-Jurczak, M. Selecting sustainability indicators for local community —Case study of Milanówek municipality, Poland. Probl. Sustain. Dev. 2012, 7, 77-86.

60. He, J.; Bao, C.K.; Shu, T.F.; Yun, X.X.; Jiang, D.; Brwon, L. Framework for integration of urban planning, strategic environmental assessment and ecological planning for urban sustainability within the context of China. Environ. Impact Assess. Rev. 2011, 31, 549-560. [CrossRef]

61. Huang, S.-L.; Yeh, C.-T.; Budd, W.W.; Chen, L.-L. A sensitivity model (SM) approach to analyze urban development in Taiwan based on sustainability indicators. Environ. Impact Assess. Rev. 2009, 29, 116-125. [CrossRef]

62. Huang, C.-L.; Vause, J.; Ma, H.-W.; Yu, C.-P. Using material/substance flow analysis to support sustainable development assessment: A literature review and outlook. Resour. Conserv. Recycl. 2012, 68, 104-116. [CrossRef]

63. Huang, Q.; Zheng, X.; Hu, Y. Analysis of land-use emergy indicators based on urban metabolism: A case study for Beijing. Sustainability 2015, 7, 7473-7491. [CrossRef] 
64. Huang, L.; Wu, J.; Yan, L. Defining and measuring urban sustainability: A review of indicators. Landsc. Ecol. 2015, 30, 1175-1193. [CrossRef]

65. Komeily, A.; Srinivasan, R.S. A need for balanced approach to neighborhood sustainability assessments: A critical review and analysis. Sustain. Cities Soc. 2015, 18, 32-43. [CrossRef]

66. Kropp, W.W.; Lein, J.K. Scenario analysis for urban sustainability assessment: A spatial multicriteria decision-analysis approach. Environ. Pract. 2013, 15, 133-146. [CrossRef]

67. Lavalle, C.; Demicheli, L.; Turchini, M.; Casals-Carrasco, P.; Niederhuber, M. Monitoring megacities: The MURBANDY/MOLAND approach. Dev. Pract. 2001, 11, 350-357. [CrossRef]

68. Lin, J.; Li, Y.; Wang, W.; Cui, S.; Wei, X. An eco-efficiency-based urban sustainability assessment method and its application. Int. J. Sustain. Dev. World Ecol. 2010, 17, 356-361. [CrossRef]

69. Masnavi, M.R. Measuring urban sustainability: Developing a conceptual framework for bridging the gap between theoretical levels and the operational levels. Int. J. Environ. Res. 2007, 1, 188-197.

70. McGranahan, G.; Satterthwaite, D. Urban centers: An assessment of sustainability. Annu. Rev. Environ. Resour. 2003, 28, 243-274. [CrossRef]

71. Michael, F.L.; Noor, Z.Z.; Figueroa, M.J. Review of urban sustainability indicators assessment—Case study between Asian countries. Habitat Int. 2014, 44, 491-500. [CrossRef]

72. Mitropoulos, L.K.; Prevedouros, P.D. Urban transportation vehicle sustainability assessment with a comparative study of weighted sum and fuzzy methods. J. Urban Plan. Dev. 2016, 142. [CrossRef]

73. Mörtberg, U.; Haas, J.; Zetterberg, A.; Franklin, J.P.; Jonsson, D.; Deal, B. Urban ecosystems and sustainable urban development-analysing and assessing interacting systems in the Stockholm region. Urban Ecosyst. 2013, 16, 763-782. [CrossRef]

74. Mori, K.; Christodoulou, A. Review of sustainability indices and indicators: Towards a new city sustainability index (CSI). Environ. Impact Assess. Rev. 2012, 32, 94-106. [CrossRef]

75. Munier, N. Methodology to select a set of urban sustainability indicators to measure the state of the city, and performance assessment. Ecol. Indic. 2011, 11, 1020-1026. [CrossRef]

76. Reith, A.; Orova, M. Do green neighbourhood ratings cover sustainability? Ecol. Indic. 2015, 48, 660-672. [CrossRef]

77. Ries, M.; Trotz, M.; Vairavamoorthy, K. Fit-for-purpose sustainability index: A simplified approach for U.S. water utility sustainability assessment. Water Pract. Technol. 2016, 11, 35-47. [CrossRef]

78. Schetke, S.; Haase, D.; Kötter, T. Towards sustainable settlement growth: A new multi-criteria assessment for implementing environmental targets into strategic urban planning. Environ. Impact Assess. Rev. 2012, 32, 195-210. [CrossRef]

79. Sciopini, A.; Mazzi, A.; Zuliani, F.; Mason, M. The ISO 14031 standard to guide the urban sustainability measurement process: An Italian experience. J. Clean. Prod. 2007, 16, 1247-1257. [CrossRef]

80. Sharifi, A.; Murayama, A. A critical review of seven selected neighborhood sustainability assessment tools. Environ. Impact Assess. Rev. 2013, 38, 73-87. [CrossRef]

81. Sharifi, A.; Murayama, A. Viability of using global standards for neighborhood sustainability assessment: Insights from a comparative case study. J. Environ. Plan. Manag. 2015, 58, 1-23. [CrossRef]

82. Shen, L.; Ochoa, J.J.; Shah, M.N.; Zhang, X. The application of urban sustainability indicators - a comparison between various practices. Habitat Int. 2011, 35, 17-29. [CrossRef]

83. STAR Community Rating System Version 2; STAR Communities: Washington, DC, USA, 2016; pp. 1-141.

84. Sun, L.; Ni, J.; Borthwick, A.G.L. Rapid assessment of sustainability in mainland China. J. Environ. Manag. 2010, 91, 1021-1031. [CrossRef] [PubMed]

85. Tran, L. An interactive method to select a set of sustainable urban development indicators. Ecol. Indic. 2016, 61, 418-427. [CrossRef]

86. U.S. Green Building Council. LEED v 4 for Neighborhood Development; U.S. Green Building Council: Washington, DC, USA, 2016; pp. 1-161.

87. Van Dijk, M.P.; Mingshun, Z. Sustainability indices as a tool for urban managers, evidence from four medium-sized Chinese cities. Environ. Impact Assess. Rev. 2005, 25, 667-688. [CrossRef]

88. Venkatesh, G.; Brattebo, H.; Saegrov, S.; Behzadian, K.; Kapelan, Z. Metabolism-modelling approaches to long-term sustainability assessment of urban water services. Urban Water J. 2016, 14, 11-22. [CrossRef]

89. Verovsek, S.; Juvancic, M.; Zupancic, T. Recognizing and fostering local spatial identities using a sustainability assessment framework. Ann. Anali Za Istrske Mediter. Stud. Ser. Hist. Sociol. 2016, 26, 573-584. 
90. Wangel, J.; Wallhagen, M.; Malmqvist, T.; Finnveden, G. Certification systems for sustainable neighbourhoods: What do they really certify? Environ. Impact Assess. Rev. 2016, 56, 200-213. [CrossRef]

91. Wei, Y.; Huang, C.; Lam, P.T.I.; Sha, Y.; Feng, Y. Using urban-carrying capacity as a benchmark for sustainable urban development: an empirical study of Beijing. Sustainability 2015, 7, 3244-3268. [CrossRef]

92. Yin, K.; Wang, R.; An, Q.; Yao, L.; Liang, J. Using eco-efficiency as an indicator for sustainable urban development: A case study of Chinese provincial capital cities. Ecol. Indic. 2014, 36, 665-671. [CrossRef]

93. Yoon, J.; Park, J. Comparative analysis of material criteria in neighborhood sustainability assessment tools and urban design guidelines: Cases of the UK, the US, Japan, and Korea. Sustainability 2015, 7, 14450-14487. [CrossRef]

94. Zanella, A.; Camanho, A.S.; Dias, T.G. The assessment of cities' livability integrating human wellbeing and environmental impact. Ann. Oper. Res. 2015, 226, 695-726. [CrossRef]

95. Cohen, M.; Wiek, A.; Kay, B.; Harlow, J. Aligning public participation to stakeholders' sustainability literacy-A case study on sustainable urban development in Phoenix, Arizona. Sustainability 2015, 7, 8709-8728. [CrossRef]

96. Robinson, J. Squaring the circle? Some thoughts on the idea of sustainable development. Ecol. Econ. 2004, 48, 369-384. [CrossRef]

97. Redclift, M. An oxymoron comes of age. Sustain. Dev. 2005, 13, 212-227. [CrossRef]

98. Collins, J.C.; Porras, J.I. Building your company's vision. Harv. Bus. Rev. 1996, September-October, 65-77.

99. Nevens, F.; Dessein, J.; Meul, M.; Rogge, E.; Verbruggen, I.; Mulier, A.; Van Passel, S.; Lepoutre, J.; Hongenaert, M. 'On tomorrow's grounds', Flemish agriculture in 2030: A case of participatory translation of sustainability principles into a vision for the future. J. Clean. Prod. 2008, 16, 1062-1070. [CrossRef]

100. Miller, T.R.; Wiek, A.; Sarewitz, D.; Robinson, J.; Olsson, L.; Kriebel, D.; Loorbach, D. The future of sustainability science: A solutions-oriented research agenda. Sustain. Sci. 2014, 9, 239-246. [CrossRef]

101. Reed, M.S.; Fraser, E.D.G.; Dougill, A.J. An adaptive learning process for developing and applying sustainability indicators with local communities. Ecol. Econ. 2006, 59, 406-418. [CrossRef]

(C) 2017 by the author. Licensee MDPI, Basel, Switzerland. This article is an open access article distributed under the terms and conditions of the Creative Commons Attribution (CC BY) license (http:/ / creativecommons.org/licenses/by/4.0/). 